\title{
Overconfidence and the Timing of Share Repurchases
}

\author{
Jonathan Handy \\ Furman University
}

This paper investigates the efficiency of open market repurchases across managerial confidence types and finds that moderately confident managers repurchase shares at relatively lower prices than overconfident managers and do so at prices that are closer to the quarterly low stock price. Additionally, it analyzes bid-ask spreads to investigate whether or not the market perceives repurchases to be wellformed and signaling undervaluation. The results suggest that repurchases by moderately confident managers are informed attempts to time the market, while repurchases by overconfident managers are either ill-informed or made for other reasons.

Keywords: Managerial Overconfidence, Overconfidence, Repurchases, Buybacks.

\section{INTRODUCTION}

"Charlie [Munger] and I favor repurchases when two conditions are met: first, a company has ample funds to take care of the operational and liquidity needs of its business; second, its stock is selling at a material discount to the company's intrinsic business value, conservatively calculated. We have witnessed many bouts of repurchasing that failed our second test. Sometimes, of course, infractions-even serious ones-are innocent; many CEOs never stop believing their stock is cheap."

-Warren Buffett, 2012 Berkshire Hathaway Shareholder Letter

A great deal of research has focused on whether managers can successfully time the market with their share repurchase behavior. This paper addresses a question that the literature has left unanswered to this point: do particular types of managers have more skill than others in repurchasing shares at relatively attractive prices? That is, are there some behavioral characteristics that make certain managers better at timing the market than others? This paper addresses this important issue through the lens of managerial confidence. As the statement by Warren Buffett suggests, many managers seem to perpetually overvalue their shares. Since such views likely reflect a confidence bias on behalf of the manager, it is appropriate to test whether managerial overconfidence impacts stock repurchase timing quality. This paper claims that overconfident managers consistently repurchase shares at higher prices than their moderately confident peers.

An issue of obvious importance when measuring repurchase timing is the timing horizon. Most prior papers examine relatively narrow windows, such as days or months surrounding the repurchase. For example, Cook, Krigman, and Leach (2004) use survey data and examine intraday timing as well as costs 
versus a benchmark over the repurchase program life. Their sample generally consists of programs completed within one year or less. Brockman and Chung (2001) study Hong Kong repurchases from the 1990's and also show evidence consistent with timing ability over relatively short horizons. Ben-Raphael, Oded, and Wohl (2014) use newer monthly data on U.S. repurchases and show evidence of timing ability within the month of the repurchase. Dittmar and Field (2015) use monthly data and find similar results, but also look at longer windows around the repurchase month. Altogether, there is substantial evidence that firms have the ability to appropriately time the execution of their share repurchase programs.

As noted by Bonaime, Hankins, and Jordan (2014), evidence favoring timing masks an important time series feature of repurchases documented by Dittmar and Dittmar (2008). Dittmar and Dittmar show that repurchases are highly procyclical, with firms aggregately spending large sums of money to repurchase shares during high valuation periods. Thus, from this perspective it appears that firms are, on average, poor at timing their repurchases. Bonaime et al. recognize this and measure "market timing" differently, by examining whether a firm's managers choose the best quarters in which to repurchase shares from a valuation perspective. They show that managers generally do a poor job of choosing when to repurchase stock. Their results suggest that managers tend to repurchase at prices that are too high and propose that a simple payout plan that repurchases a set number of shares each quarter would result in a "rate of return" on repurchases that is about 200 basis points higher per year. This paper follows the framework of Bonaime et al. and compares prices in repurchasing quarters with prices in nonrepurchasing quarters.

In addition to the Bonaimé et al. framework, this paper incorporates known behavioral biases by separating managers into differing managerial confidence types-moderately confident and overconfident. Many studies attribute significant bias to overconfidence and show large impacts upon corporate decision making and firm value, including investment distortions (Malmendier \& Tate, 2005), increased managerial turnover (Campbell, Johnson, Rutherford, \& Stanley, 2009), capital structure changes (Malmendier, Tate, \& Yan, 2011), and increased merger and acquisition activity (Malmendier \& Tate, 2008). This paper expands upon these findings by suggesting that biases arising from overconfidence also affect corporate payout policy and repurchasing behavior. Malmendier and Tate suggest that overconfident managers hold the personal belief that the market undervalues their ability to positively influence future firm value and, thus, believe that the market systematically undervalues their firm. This skewed view should naturally affect the repurchasing decision-overconfident managers should be more apt to repurchase at higher prices and repurchase less effectively than their peers because from the manager's perspective, stock underpricing is much more likely. By comparing the average stock price in quarters where the firm repurchased shares to the average stock price in quarters without repurchasing and taking the difference (referred to as the repurchase efficiency spread), the results of Bonaime et al. are confirmed. Interestingly, this difference is especially large for firms with overconfident managers, which suggests that they are especially poor at timing repurchases.

This paper tests a variety of confidence groups based upon Thomson Reuters' insider classes. The results differ across classes, but the main result is that the more moderately confident (i.e. less overconfident) managers/insiders are within a firm, the more efficiently that firm repurchases stock. Conversely, as a firm becomes more overconfident, the price difference between repurchase quarters and non-repurchase quarters increases. The primary consideration is of CEOs and CFOs, as they are likely to have the most responsibility for the timing and execution of open market repurchases. All of the general results continue to hold when including all corporate insiders - as the number of overconfident insiders increases, repurchasing efficiency decreases.

This repurchase efficiency analysis suggests that moderately confident firms repurchase more efficiently and are more likely to be timing the market. As such, there may be a difference in how the market views a firm's repurchases - firms led by moderately confident managers may be viewed by the market as more informed relative to those led by overconfident managers. As first proposed by Barclay and Smith (1988), this could lead to a differential impact on market liquidity for the firm's shares. This paper finds evidence consistent with this. When firms with moderately confident managers are actively repurchasing shares, the bid-ask spreads are relatively wider than when overconfident managers are 
repurchasing. This result is generally consistent with Barclay and Smith's asymmetric information hypothesis, but only for firms that the market views as informed; if the market views the firm as less informed (overconfident firms), then the competing market maker hypothesis of Barclay and Smith dominates and spreads are relatively lower.

This paper is related to two recent papers that investigate the interaction of overconfidence and repurchase behavior. Andriosopoulos, Andriosopoulos, and Hoque (2013) show that overconfident managers in the UK are likelier to complete their announced buyback programs. However, rather than buyback completion, this paper focuses on the quality of long-term repurchase timing. Banerjee, Humphery-Jenner, and Nanda (2015) show that overconfident managers are likelier to announce repurchases than dividends, and that the market reacts less positively to repurchase announcements by these firms. This paper's results complement those of Banerjee et al., by providing potential evidence on why the market responds less favorably to such repurchases.

The remainder of this paper is organized as follows. Section 1 reviews the previous literature and hypothesis development. Section 2 describes the data and provides summary statistics. Section 3 describes the methodology and presents results. Section 4 offers conclusions.

\section{LITERATURE REVIEW AND HYPOTHESIS DEVELOPMENT}

\section{Managerial Overconfidence}

The finding that managerial overconfidence can account for corporate investment distortions drives this paper. Managerial overconfidence is rooted in the social psychology concept known as the "betterthan-average" effect. Research findings suggest that individuals often overestimate their own decisionmaking prowess compared to the average individual (Alicke, 1985; Camerer \& Lovallo, 1999; Larwood \& Whittaker, 1977; Svenson, 1981). Accordingly, overconfident individuals are also likelier to reject ownership of bad outcomes, while taking credit for all good, positive outcomes. (Miller \& Ross, 1975). Three primary factors have been associated with eliciting overconfidence: illusions of control, an overzealous degree of commitment to good outcomes, and difficulty comparing performance across individuals (Alicke, Klotz, Breitenbecher, Yurak, \& Vredenburg, 1995; Weinstein, 1982). Theoretical work by Goel and Thakor (2008) suggests that the nature of the corporate hiring process is biased against hiring moderately confident individuals and that managers in the corporate world's upper echelons should be overconfident. It is important to mention, though, that while all CEOs may indeed be overconfident compared to the average individual, overconfidence among CEOs can range from under-confident (least overconfident CEOs) to overconfident (highly overconfident CEOs). The confidence measures should be interpreted accordingly.

Malmendier and Tate's (2005) finding that corporate investment is highly sensitive to cash flow when managed by an overconfident CEO is this paper's behavioral foundation. Overconfident managers believe the market incorrectly undervalues their firm due to its inability to accurately gauge his or her ability to positively influence future earnings. Accordingly, the manager believes the prevailing stock price is too low and the choice to rely on equity as a capital source is less attractive. If this is true for the decision to issue equity, it is also likely to affect the decision to repurchase equity. Thus, payout policy for firms with overconfident managers may differ systematically from payout policies for firms with moderately confident managers because of differing views regarding their firm's stock valuation.

\section{Stock Repurchases}

There are five traditionally held repurchasing reasons (see Dittmar (2000) for a thorough analysis). The hypotheses in this work are on the following two: that firms repurchase to distribute excess cash to shareholders and to capitalize on potential market mispricing.

Jensen (1986) suggests high free cash flow can create substantial conflicts of interest between shareholders and management and result in high agency costs. By distributing this cash flow to investors, either by paying a dividend or repurchasing stock, such problems can potentially be avoided. Managers often prefer open market repurchases to dividend payments because of the increased flexibility afforded 
the firm. For example, firms who stop paying dividends are generally penalized by the markets, while firms who fail to repurchase stock after an announcement, or who fail to complete a repurchase, are not (Bajaj \& Vijh, 1990; Brav, Graham, Harvey, \& Michaely, 2005; Denis, Denis, \& Sarin, 1994; Kaplan \& Reishus, 1990).

The flexible timing afforded by repurchase plans may also contribute to their popularity. Unlike dividends, repurchases can essentially be made whenever management deems them advantageous, potentially allowing management to time their repurchases around periods of seeming market undervaluation. Differing information levels between corporate insiders and investors may lead to situations where better-informed insiders believe the market has incorrectly priced company stock too low. The undervaluation hypothesis suggests that a firm repurchases stock to signal undervaluation to the market. To the extent that certain behaviors distort a manager's valuation of the firm, one would expect these behaviors to affect stock repurchases. Since overconfident managers are likelier to believe the firm is undervalued, overconfident CEOs should be more prone to repurchase stock to correct for this. Additionally, a question of particular interest is whether or not overconfident CEOs repurchase during points where their firm is actually undervalued and whether or not they purchase at the best price. If overconfident CEOs believe the market systematically undervalues the firm then one would expect them to make repurchases at higher prices than moderately confident CEOs. Indeed, as overconfidence increases, firms may repurchase stock at prices high enough that the equity repurchases actually lower firm value, at least from the perspective of remaining shareholders.

\section{DATA}

\section{Repurchase Data}

This paper focuses primarily on the U.S. firms in the merged CRSP/Compustat universe. It follows a similar data collection process to Bonaime et al. (2014). In order to appear in the sample, a firm must have repurchased shares in at least one quarter over the period 1993-2010, and qualifies to enter the sample upon repurchasing an amount that is at least 0.1 percent of its market capitalization. For each quarter, the dollar value spent on share repurchases is calculated as specified by the Compustat quarterly purchase of common and preferred stock. This variable is a year-to-date cumulative variable, and as such it is lagged across quarters and has previous repurchases netted out. Firms are required to have a CRSP share code of 10 or 11, and any observation where the beginning-of-quarter stock price is less than or equal to $\$ 5$ is removed. Table 1 describes the final repurchase sample. 


\section{TABLE 1}

\section{SHARE REPURCHASE DESCRIPTIVE STATISTICS}

Panel A: Unclassified

VARIABLES

Repurchases (millions \$)

Repurchases greater than $\$ 0$ (millions \$)

\begin{tabular}{rrcccc} 
& & Standard & \multicolumn{3}{c}{ Percentiles } \\
\cline { 4 - 6 } $\mathrm{N}$ & Mean & Deviation & 25th & 50th & 75th \\
\hline 101,096 & 21.46 & 77.8300 & 0.0000 & 0.0000 & 2.2100 \\
41,734 & 51.99 & 114.4000 & 0.6700 & 5.0000 & 35.8000
\end{tabular}

Repurchases (\% of market capitalization)

$\begin{array}{llllll}101,096 & 0.0048 & 0.0120 & 0.0000 & 0.0000 & 0.0035\end{array}$

Repurchases if greater than $0 \%$ (\% of market capitalization)

$41,527 \quad 0.012 \quad 0.0160$

$0.0015 \quad 0.0057 \quad 0.0150$
Repurchase greater than $0.1 \%$

Repurchase greater than $1.2 \%$ (firm-level mean)

\begin{tabular}{cccccc}
33,037 & 0.015 & 0.0170 & 0.0037 & 0.0084 & 0.0180 \\
12,453 & 0.03 & 0.0190 & 0.0160 & 0.0230 & 0.0370 \\
\hline
\end{tabular}

Panel B: Moderately Confident

VARIABLES

Repurchases (millions \$)

Repurchases greater than $\$ 0$ (millions $\$$ )

Repurchases ( $\%$ of market capitalization)

$15,584 \quad 0.0061$

$6,955 \quad 0.014 \quad 0.0180$

Repurchases if greater than $0 \%$ (\% of market capitalization)

$6,955 \quad 0.014$

Standard

Deviation

59.2900

84.6400
0.0000

0.0000

0.0052

Percentiles

$\begin{array}{ccc}25 \text { th } & \text { 50th } & 75 \text { th } \\ 0.0000 & 0.0000 & 2.9800 \\ 0.6400 & 4.6300 & 26.9000\end{array}$

$\begin{array}{lll}0.0017 & 0.0068 & 0.0180\end{array}$

Repurchase greater than $0.1 \%$

$\begin{array}{llllll}5,659 & 0.017 & 0.0190 & 0.0041 & 0.0099 & 0.0210\end{array}$

Repurchase greater than $1.2 \%$ (firm-level mean)

\begin{tabular}{llllll}
2,480 & 0.031 & 0.0200 & 0.0170 & 0.0240 & 0.0390 \\
\hline
\end{tabular}

Panel C: Overconfident

VARIABLES

Repurchases (millions \$)

\begin{tabular}{lccccc} 
& & Standard & \multicolumn{3}{c}{ Percentiles } \\
\cline { 4 - 6 } $\mathrm{N}$ & Mean & Deviation & 25th & 50th & 75th \\
\hline 31,248 & 10.98 & 51.1500 & 0.0000 & 0.0000 & 1.3100 \\
13,230 & 25.93 & 76.1000 & 0.3900 & 2.4400 & 13.8800
\end{tabular}

Repurchases greater than $\$ 0$ (millions $\$$ )

$\begin{array}{cccccc}31,248 & 0.0052 & 0.0130 & 0.0000 & 0.0000 & 0.0036 \\ 13,151 & 0.012 & 0.0170 & 0.0014 & 0.0056 & 0.0150\end{array}$

Repurchases ( $\%$ of market capitalization)

13.151 $0.012-0.0170$

Repurchases if greater than $0 \%$ ( $\%$ of market capitalization)

Repurchase greater than $0.1 \%$

\begin{tabular}{rrrrrr}
10,359 & 0.016 & 0.0180 & 0.0037 & 0.0085 & 0.0190 \\
4,042 & 0.032 & 0.0200 & 0.0170 & 0.0240 & 0.0410 \\
\hline
\end{tabular}

Repurchase greater than $1.2 \%$ (firm-level mean)

$\begin{array}{cccccc}4,042 & 0.032 & 0.0200 & 0.0170 & 0.0240 & 0.0410\end{array}$ This table presents quarterly summary statistics describing the magnitude and firms. Unclassified firms are those firms where the company CEO made zero personal purchases of company
sample firms. stock within the sample period 1993-2010. In accordance with the overconfidence measure of Kolasinski and Li (2013), CEOs are classified as moderately confident if they have an average non-negative 180-day abnormal return following the insider purchase. CEOs are classified as overconfident if they have an average negative 180-day abnormal return following the insider purchase. 


\section{Overconfidence Measures}

Multiple confidence measures exist, and while the Malmendier and Tate Longholder overconfidence measure is currently more popular in the literature, the classification method used by Kolasinski and $\mathrm{Li}$ (2013) is the main focus of this work. ${ }^{2}$ In general, the Longholder measure classifies CEOs as overconfident if they hold options until expiration, well past the point when they should have exercised them from an optimal diversification perspective. These option-based confidence classification methods can require extensive and costly hand-collection and/or may restrict observation to only a subset of corporations (e.g. Longholder requires firms to issue employee stock options). In contrast, Kolasinski and Li's method is able to sweep through all firms easily, looking simply at personal insider company stock purchases. Data on these purchases are obtained from Thomson Reuters Insiders Information Table I. Kolasinski and Li identify as overconfident "those CEOs who purchase their own company's stock in the secondary market and who ex post earn a negative abnormal return over the next 180 days." By purchasing at prices that are too high, they reveal their (mistaken) belief that their own firm is undervalued, suggesting that they are overconfident. Additionally, Kolasinski and Li's measure is very similar in spirit to Malmendier and Tate's "Longholder: should have exercised" overconfidence measure, which classifies CEOs as overconfident based on option holdings only when holding until expiration results in negative abnormal returns.

CEO insider purchase data is obtained from the Thomson Reuters Insiders Information database (from 1993 to 2010.) The abnormal returns over the following 180-day window are then computed after each insider purchase. In keeping with the method of Kolasinski and Li (2013), abnormal returns are defined as the buy-and-hold return to the CEO's firm's stock less the buy-and-hold return of the CRSP value-weighted size decile index to which the CEO's firm belongs. Firm-year observations are classified as having an overconfident $\mathrm{CEO}$ if, relative to the current year, the following two calendar years contain CEO purchases that have a negative 180-day abnormal return on average. For example, a CEO would be declared overconfident in 2005 if the 180-day average abnormal return of his insider stock purchases in 2006 and 2007 is less than zero. In the event that one year's abnormal returns should be directly offset by another year's (e.g., 2006 average abnormal return of $-20 \%$ and 2007 abnormal return $+20 \%$ ), the more conservative outcome is chosen and the manager is labeled as moderately confident. Repurchases are classified as overconfident if the CEO has been determined to be overconfident at least once during the sample period. Once a CEO has been declared overconfident at least once, he or she is declared overconfident for the remainder of the sample. The same procedure is used when analyzing other insiders. See Appendix A for a complete listing of Thomson Reuters Insiders codes and group classifications. Table 2 provides sample descriptive statistics classified by CEO overconfidence and repurchase status. 
TABLE 2

SUMMARY STATISTICS ACROSS CONFIDENCE TYPE AND REPURCHASE QUARTERS

Panel A:

\begin{tabular}{lcccccccccc}
\hline & \multicolumn{3}{c}{ Unclassified } & \multicolumn{3}{c}{ Moderately Confident } & \multicolumn{3}{c}{ Overconfident } \\
\cline { 2 - 10 } VARIABLES & $\mathrm{N}$ & mean & $\mathrm{sd}$ & $\mathrm{N}$ & mean & $\mathrm{sd}$ & $\mathrm{N}$ & $\mathrm{mean}$ & $\mathrm{sd}$ \\
\hline & & & & & & & & & \\
Total Assets & $111,310.00$ & $4,885.19$ & $15,100.81$ & $17,235.00$ & $3,860.24$ & $13,053.17$ & $37,700.00$ & $3,699.65$ & $13,607.24$ \\
Total Liabilities & $111,295.00$ & $3,407.81$ & $11,637.39$ & $17,229.00$ & $2,915.93$ & $10,688.87$ & $37,691.00$ & $2,847.69$ & $11,118.86$ \\
Shares Outstanding & $111,018.00$ & 103.43 & 244.10 & $17,199.00$ & 70.58 & 144.63 & $37,656.00$ & 67.67 & 166.78 \\
Short-term Debt & $105,206.00$ & 234.00 & 930.03 & $16,239.00$ & 158.89 & 708.23 & $35,770.00$ & 165.76 & 766.87 \\
Long-term Debt & $110,360.00$ & 857.83 & $2,443.66$ & $17,039.00$ & 689.66 & $2,045.33$ & $37,404.00$ & 677.45 & $2,208.82$ \\
Dividends & $111,412.00$ & 0.26 & 1.28 & $17,253.00$ & 0.19 & 1.12 & $37,684.00$ & 0.22 & 1.13 \\
Net Income & $111,398.00$ & 47.58 & 154.13 & $17,249.00$ & 26.62 & 94.27 & $37,678.00$ & 18.72 & 99.28 \\
Earnings Per Share & $111,197.00$ & 0.33 & 0.51 & $17,235.00$ & 0.29 & 0.47 & $37,658.00$ & 0.18 & 0.49 \\
Retained Earnings & $107,572.00$ & 888.15 & $2,504.09$ & $16,813.00$ & 388.16 & $1,389.58$ & $37,187.00$ & 297.92 & $1,508.99$ \\
Stockholders' Equity & $111,314.00$ & $1,286.04$ & $3,150.06$ & $17,230.00$ & 875.69 & $2,348.94$ & $37,697.00$ & 779.80 & $2,338.46$
\end{tabular}

This table presents quarterly summary statistics on basic balance sheet and cash flow entries. Unclassified firms are those where the CEO made zero personal purchases of company stock within the sample period 1993-2010. In accordance with the overconfidence measure of Kolasinski and Li (2013), CEOs are classified as moderately confident if they have an average non-negative 180-day abnormal return following the insider purchase. CEOs are classified as overconfident they have an average negative 180-day abnormal return following the stock purchase. Panel A presents quarterly summary statistics according to confidence type.

\section{Trade and Quote Liquidity Data}

All liquidity data is taken from the NYSE Trade and Quote (TAQ) database, which contains intraday transaction data for all securities. For each firm quarter within the sample, the average percentage bid-ask spread is calculated over the quarter. All quotes are collected (filtered following the rules in Weston (2000)) during regular trading hours for each stock, and then the average daily percentage spread is calculated. The average across all trading days in the quarter is then taken to find each stock's average quarterly bid-ask spread. Due to data limitations, when utilizing TAQ data the sample is limited to the period 2000-2010.

\section{METHODOLOGY AND RESULTS}

\section{Open Market Repurchase Efficiency and Managerial Overconfidence}

As in Bonaime et al. (2014), a repurchase is defined as more efficient than another if the estimated purchase price is lower relative to the price benchmarks or valuation ratios occurring in non-repurchase quarters. The higher the repurchase price (or valuation ratio) is relative to non-repurchasing quarters the lower the company's repurchase efficiency, because the firm could have repurchased at a lower price had they repurchased in a different quarter. For example, a firm's market-to-book ratio (M/B ratio) is one valuation ratio used. Since company stock price is embedded within the ratio, one is able to make conclusions about a company's repurchase timing behavior by comparing one quarter's M/B ratio with another. In the event that the $\mathrm{M} / \mathrm{B}$ ratio in a repurchase quarter is lower than the $\mathrm{M} / \mathrm{B}$ ratio in a nonrepurchase quarter, the repurchase is considered well-timed. The converse would imply a poor repurchase. An alternative, more general, interpretation for the $\mathrm{M} / \mathrm{B}$ ratio analysis that still explains market timing efficiency is used by Dittmar (2000). According to earlier findings by Lakonishok, Shleifer, and Vishny (1994) and Ikenberry et al. (1995), showing that firms with low market-to-book ratios earn positive abnormal returns in the following quarters, Dittmar uses the $\mathrm{M} / \mathrm{B}$ ratio as a general proxy for undervaluation. Such an interpretation should suffice here as well. 
This paper's market timing method differs from that of most previous studies, which analyze only within-quarter or within-month repurchase quality and look across quarters. For each firm, the minimum daily stock price, the daily closing price, and the maximum daily stock price are each averaged across the total number of trading days within the quarter. Efficiency measures using the minimum daily stock price can be seen as a best-case scenario, while the maximum daily stock price is a worst-case scenario. Since open market repurchases (OMRs) cannot be made at prices that are lower (higher) than the quarterly minimum (maximum) daily stock price, any repurchases made at those prices are the best (worst) possible repurchases during the quarter. The valuation ratios used are a firm's quarterly sales-to-price ratio and its quarterly market-to-book ratio. Next the within-firm differences in prices and valuation ratios between repurchasing and non-repurchasing quarters are calculated. To give each firm equal weight within the sample, the averages and the differences are then averaged again.

Table 3 provides the initial repurchase efficiency tests. Panel A splits the sample into repurchasing quarters or non-repurchasing quarters and further splits each category into repurchases made by an overconfident or a moderately-confident manager. Table 3 looks only at CEO and CFO confidence levels. As shown for both groups, overconfident managers appear to repurchase at prices that are relatively higher and less efficient than their moderately confident peers. For example, CEO columns 11-13 provide the average $(\log )$ minimum stock price for moderately confident and overconfident non-repurchasing quarters. For moderately confident managers, non-repurchase quarters have a minimum (log) stock price of 2.65, while repurchase quarters have a minimum $\log$ price of 2.72 . The difference is marginally significant, and suggests that prices tend to be higher on average in repurchase quarters compared to nonrepurchase quarters. The pattern for overconfident managers is similar. Overconfident managers repurchase in quarters with an average log stock price of 2.57 , which is significantly higher than nonrepurchase quarters with an average $\log$ stock price of 2.46 . What is more important, however, is the difference between moderately confident and overconfident managers. Panel B of Table 3 addresses this. The t-statistic of 3.67 shows that when considering the minimum quarterly stock price, firms with overconfident CEO's are significantly less efficient when it comes to repurchasing shares. 
TABLE 3

REPURCHASE QUALITY AND OVERCONFIDENCE—CEOS AND CFOs

Panel A : Average Differences across Non-Repurchasing Quarters and Repurchasing Quarters

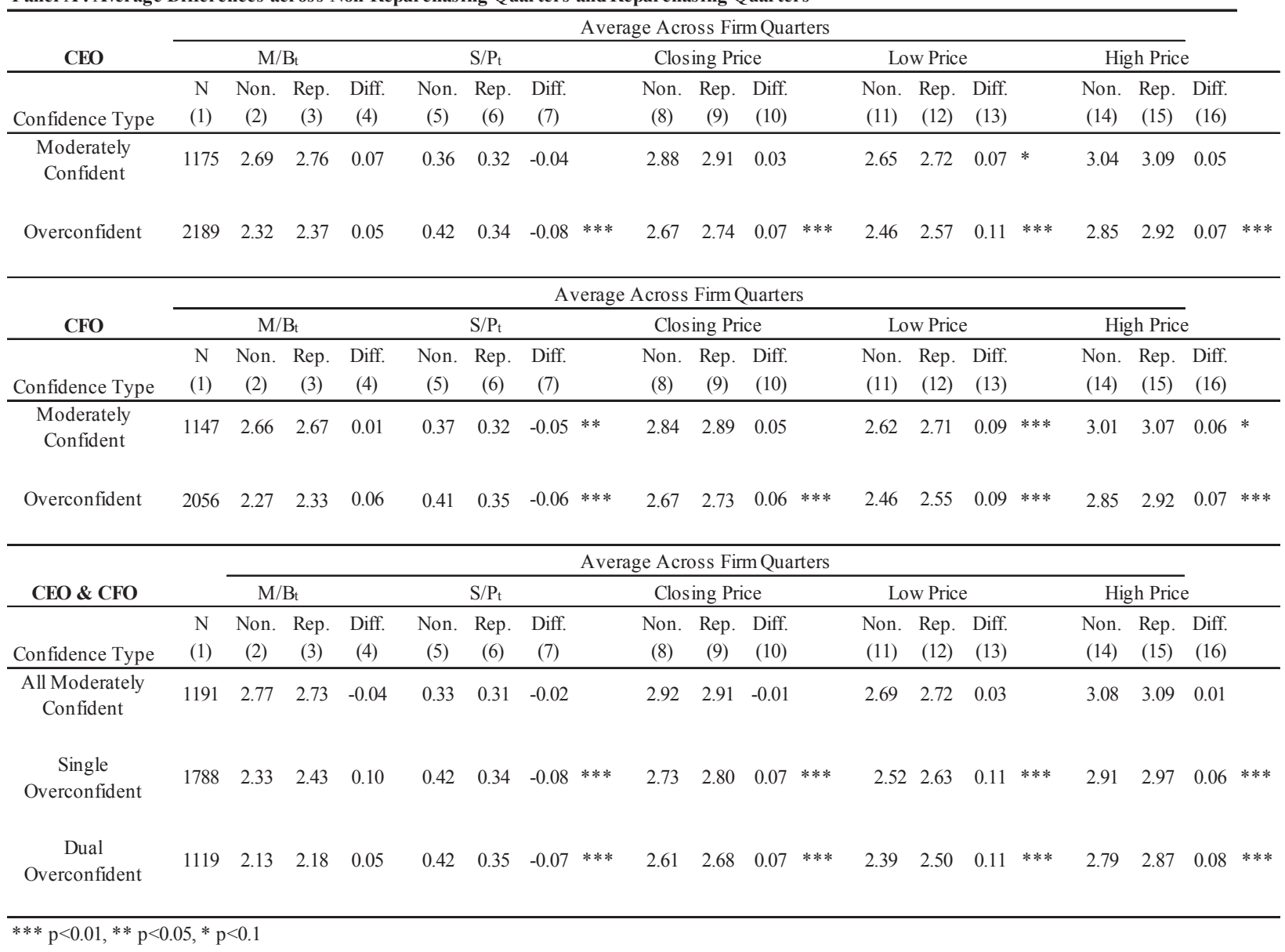


Panel B: Repurchase Price Difference Comparis on Across Confidence Types

\begin{tabular}{|c|c|c|c|c|c|}
\hline CEO & \multicolumn{5}{|c|}{ Difference-in-Differences t-Statistics } \\
\hline $\begin{array}{c}\text { Overconfidence } \\
\text { Quartile }\end{array}$ & $\mathrm{M} / \mathrm{B}_{\mathrm{t}}$ & $\mathrm{S} / \mathrm{P}_{\mathrm{t}}$ & $\begin{array}{c}\text { Average } \\
\text { Closing } \\
\text { Price } \\
\end{array}$ & $\begin{array}{c}\text { Low } \\
\text { Quarterly } \\
\text { Stock Price }\end{array}$ & $\begin{array}{c}\text { Hi } \\
\text { Quarterly } \\
\text { Stock Price }\end{array}$ \\
\hline \multirow[t]{2}{*}{ Overconfident } & 0.25 & -2.84 & 3.68 & 3.67 & 2.89 \\
\hline & \multicolumn{5}{|c|}{ Difference-in-Differences t-Statistics } \\
\hline \multicolumn{6}{|l|}{ CFO } \\
\hline Confidence Type & $\mathrm{M} / \mathrm{B}_{\mathrm{t}}$ & $\mathrm{S} / \mathrm{P}_{\mathrm{t}}$ & $\begin{array}{c}\text { Average } \\
\text { Closing } \\
\text { Price } \\
\end{array}$ & $\begin{array}{c}\text { Low } \\
\text { Quarterly } \\
\text { Stock Price }\end{array}$ & $\begin{array}{c}\text { Hi } \\
\text { Quarterly } \\
\text { Stock Price } \\
\end{array}$ \\
\hline \multirow[t]{2}{*}{ Overconfident } & 2.02 & -1.70 & 2.96 & 2.28 & 2.84 \\
\hline & \multicolumn{5}{|c|}{ Difference-in-Differences t-Statistics } \\
\hline \multicolumn{6}{|l|}{ CEO \& CFO } \\
\hline Confidence Type & $\mathrm{M} / \mathrm{B}_{\mathrm{t}}$ & $\mathrm{S} / \mathrm{P}_{\mathrm{t}}$ & $\begin{array}{c}\text { Average } \\
\text { Closing } \\
\text { Price } \\
\end{array}$ & $\begin{array}{c}\text { Low } \\
\text { Quarterly } \\
\text { Stock Price }\end{array}$ & $\begin{array}{c}\text { Hi } \\
\text { Quarterly } \\
\text { Stock Price } \\
\end{array}$ \\
\hline Single Overconfident & 1.56 & -3.39 & 5.34 & 5.39 & 4.65 \\
\hline Dual Overconfident & 1.33 & -3.82 & 5.86 & 5.55 & 5.50 \\
\hline
\end{tabular}

This table presents the within-firm averages and differences in the split-adjusted quarterly closing stock price in repurchasing quarters and non-repurchasing quarters across managerial confidence types. Firms are required to have at least one closing stock price and at least one non-repurchasing quarter to be included. Repurchasing quarters are defined as quarters where the firm repurchases a dollar amount that is at least .1 percent of its market capitalization. The average closing price is the natural log of the Compustat reported quarterly closing price. Firms are classified as overconfident based on the classification method of Kolasinski and Li (2013). Panels A and B split the three manager groups, CEO, CFO, and CEO \& CFO into confidence types. Panel A compares the average price benchmarks across repurchase quarters and non-repurchase quarters. Diff is the difference between the price benchmark in repurchase quarters and in non-repurchase quarters. Panel B tests the differences across columns 4, 7, 10, 13, and 16 for statistical significance, providing t-statistics. All price variables are winsorized at the 1st and 99th percentiles.

To this point, only repurchase efficiency using the minimum price during a quarter has been tested. A company which optimally times its repurchases should do so at the minimum stock price because to repurchase at any other price would mean it could have paid less. Such a measure, however, is a best-case scenario, and even companies who time repurchases well are unlikely to always repurchase at the lowest stock price. To this end, other timing benchmarks are included. These alternative benchmarks and valuation ratios suggest that overconfident managers consistently repurchase at prices that are too high while more moderately confident managers seemingly do not. For example, columns 5-7 use the repurchasing firm's sales-to-price ratio ( $\mathrm{S} / \mathrm{P}$ ratio) as the market timing measure. In this instance an increased $\mathrm{S} / \mathrm{P}$ ratio is desirable because as price decreases in the denominator the overall ratio increases (this, of course, assumes that an increase in sales does not systematically increase repurchases, which the author believes is unlikely.) Column 7 suggests that overconfident firms repurchase during quarters in 
which the $\mathrm{S} / \mathrm{P}$ ratio is approximately eight percentage points less than in non-repurchase quarters. Among moderately confident firms there is no statistically significant difference across quarters. Columns 8-10 look simply at average daily closing stock price during the quarter and suggest that overconfident repurchases are made in quarters where the average closing stock price is roughly $7 \%$ higher than the average non-repurchase quarter closing stock price. Within moderately confident firms there is no statistical difference in average quarterly closing stock prices. Columns 14-16 use quarterly high stock price as the benchmark. This measure can be interpreted as a worst-case scenario, as companies repurchasing at the quarterly high price are repurchasing at the worst possible price. Similar to earlier results, overconfident managers repurchase in quarters where the quarterly high stock price is higher than non-repurchase quarters. Finally, keeping with the methodology used by Bonaime et al. (2014), columns 2-4 use the company's market-to-book ratio as the valuation ratio. This is the only measure without consistent significant differences between overconfident and moderately confident CEOs; however, market-to-book ratios are inherently noisy, and with a more extreme winsorization (5\% to $95 \%$ ) the results support earlier findings.

Extending the analysis to CFOs provides similar results; however, at first glance there appears to be little difference in repurchase behavior across confidence types. For example, both moderately confident and overconfident managers appear to repurchase during quarters where the average low price is significantly higher than that in non-repurchase quarters. It is important to note, though, that it is possible for a company to have an overconfident CEO and a moderately confident CFO, or vice versa, and so be placed in the moderately confident group when in fact it may be influenced by an overconfident manager. This paper avoids this problem by splitting firms according to the overconfidence of both the CEO and the CFO. The results suggest that the presence of at least one overconfident manager significantly decreases repurchase efficiency across all efficiency measures ( $\mathrm{M} / \mathrm{B}$ ratio excluded), while having no overconfident manager suggests that repurchase premiums are statistically insignificant from zero.

Though it is likely that the CEO and the CFO have the greatest influence on repurchase decisions, one cannot rule out the possibility that other insiders also have an effect. To further test the impact of overconfidence on the repurchase decision, the ways in which managers other than the CEO/CFO might affect the repurchase decision is analyzed. Four insider groups are analyzed: All Managers, Level 1, Level 2, and Level 3. The Thomson Reuters Table I database assigns various relationship codes to corporate insiders depending upon their roles within the company. Level 1 consists of the highest-level insiders, including the Chairman of the Board, the CEO, the Chief Operating Officer, General Counsel, and the company President. Levels 2, 3, and 4 comprise insiders lower in the corporate hierarchy. Appendix A shows a list of all insider relationship codes. All Managers consists of all company insider codes available in the Thomson Reuters Table I database. Levels 1, 2, 3 correspond to the level 1, 2, and 3 subcategories within the Table I database. Within each of these groups, firms are split into quartiles based upon the firms' overconfidence level, 0 to 3 . Firms in overconfidence quartile 0 have zero overconfident insiders, while firms in later quartiles have more. Overconfidence quartile 3 is composed of firms with the most overconfident managers. The results of this analysis appear in Table 4. Overall, the results suggest that overconfident firms repurchase in relatively more expensive quarters compared to their moderately confident peers. Also, as the number of overconfident insiders increases, so too does the repurchase premium paid. This conclusion is most broadly reflected in the All Managers group. For example, columns 5-7 suggest a general decrease in the $\mathrm{S} / \mathrm{P}$ ratio across repurchase and non-repurchase quarters as overconfidence increases. Closing Price, Low Price, and High Price analysis all suggest that, at the highest level of overconfidence, repurchase quarters are associated with higher benchmark prices (a premium of between 8 to 12\%). As in Table 3, Panel A does not compare repurchase behavior across confidence types. Panel B of Table 4 provides difference-in-difference test statistics that unanimously suggest that, as firm overconfidence levels increase, so too do the premiums paid for repurchases. 
TABLE 4

\section{REPURCHASE QUALITY AND OVERCONFIDENCE - ALL INSIDERS}

Panel A : Average Differences across Non-repurchasing Quarters and Repurchasing Quarters

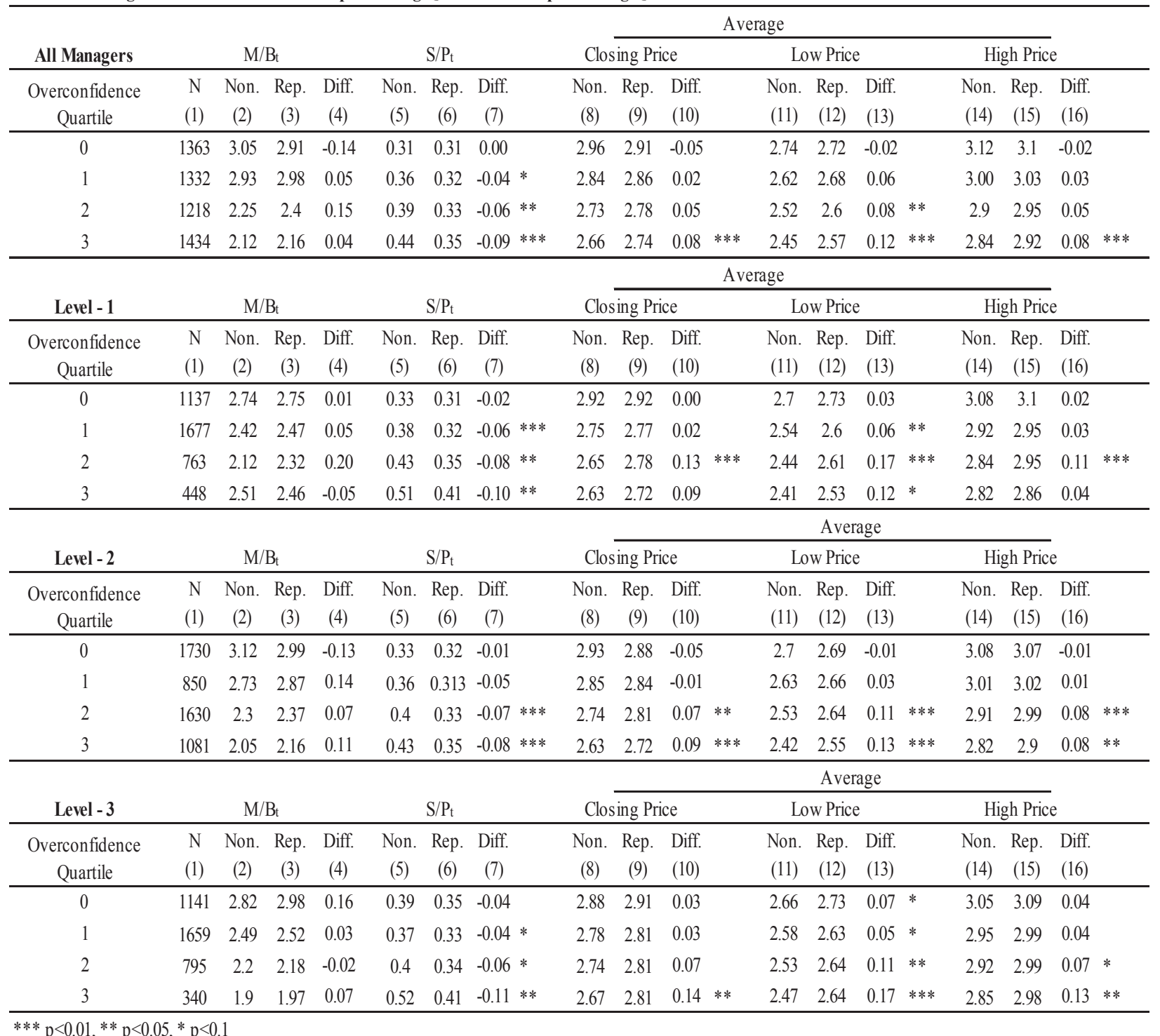

138 Journal of Accounting and Finance Vol. 19(4) 2019 
Panel B: Repurchase Price Difference Comparis on Across Confidence Types

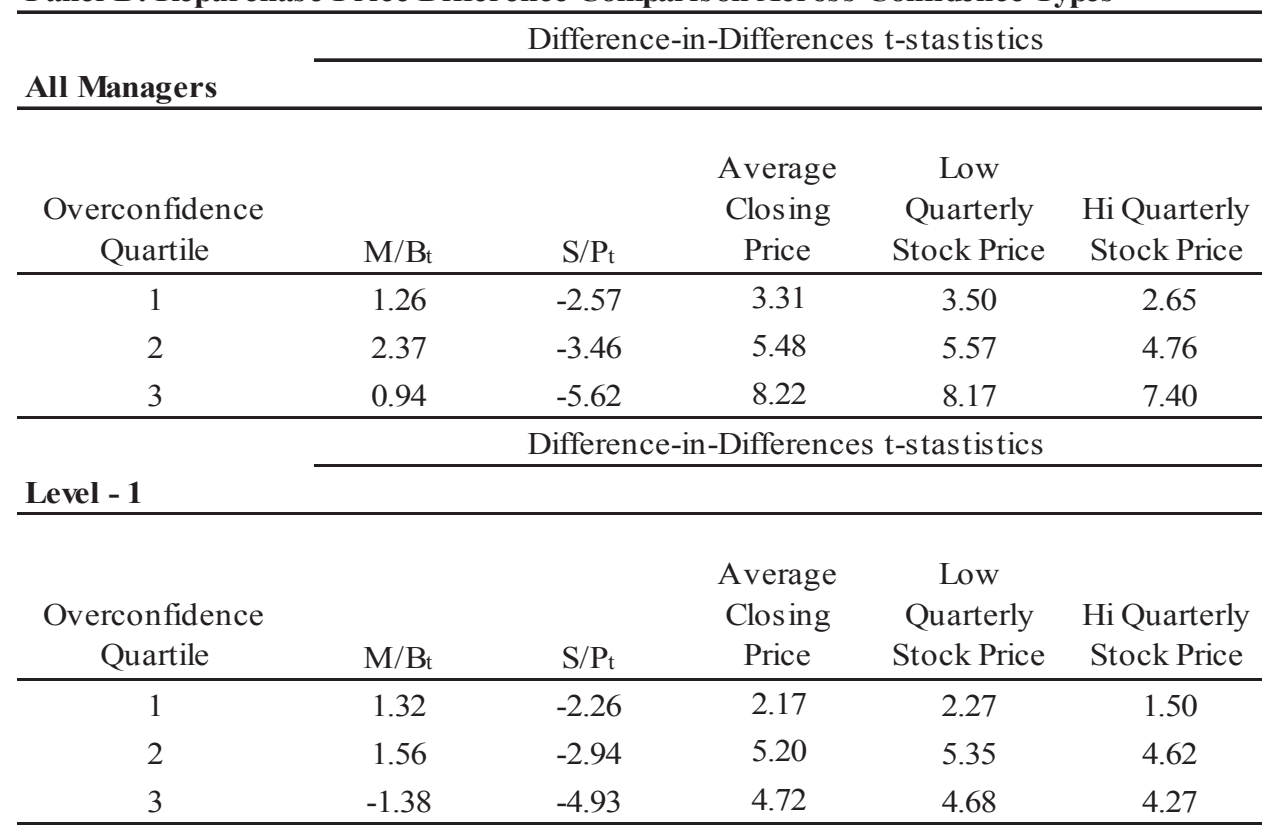

Difference-in-Differences t-stastistics

Level - 2

\begin{tabular}{|c|c|c|c|c|c|}
\hline $\begin{array}{c}\text { Overconfidence } \\
\text { Quartile }\end{array}$ & $\mathrm{M} / \mathrm{B}_{\mathrm{t}}$ & $\mathrm{S} / \mathrm{P}_{\mathrm{t}}$ & $\begin{array}{c}\text { Average } \\
\text { Closing } \\
\text { Price }\end{array}$ & $\begin{array}{c}\text { Low } \\
\text { Quarterly } \\
\text { Stock Price }\end{array}$ & $\begin{array}{l}\text { Hi Quarterly } \\
\text { Stock Price }\end{array}$ \\
\hline 1 & 1.95 & -2.15 & 2.64 & 2.40 & 2.08 \\
\hline 2 & 2.39 & -4.30 & 6.80 & 6.91 & 6.40 \\
\hline 3 & 1.64 & -5.41 & 8.52 & 8.22 & 7.57 \\
\hline
\end{tabular}

Level - 3

Difference-in-Differences t-stastistics

\begin{tabular}{|c|c|c|c|c|c|}
\hline $\begin{array}{c}\text { Overconfidence } \\
\text { Quartile }\end{array}$ & $\mathrm{M} / \mathrm{B}_{\mathrm{t}}$ & $\mathrm{S} / \mathrm{P}_{\mathrm{t}}$ & $\begin{array}{c}\text { Average } \\
\text { Closing } \\
\text { Price }\end{array}$ & $\begin{array}{c}\text { Low } \\
\text { Quarterly } \\
\text { Stock Price }\end{array}$ & $\begin{array}{l}\text { Hi Quarterly } \\
\text { Stock Price }\end{array}$ \\
\hline 1 & -0.28 & -0.87 & 2.40 & 2.38 & 2.23 \\
\hline 2 & -0.74 & -1.34 & 3.05 & 2.86 & 2.87 \\
\hline 3 & -0.35 & -3.90 & 4.61 & 4.38 & 4.31 \\
\hline
\end{tabular}

This table presents the within-firm averages and differences in the split-adjusted quarterly closing stock price in repurchasing and non-repurchasing quarters across managerial confidence type. Firms are required to have at least one closing stock price and at least one non-repurchasing quarter to be included. Repurchasing quarters are defined as quarters in which the firm repurchases a dollar amount that is at least .01 percent of its market capitalization. The average closing price is the natural log of the Compustat reported quarterly closing price. Firms are classified as overconfident based on the classification method of Kolasinski and Li (2013). Panels A and B split the manager groups-All, Level 1, Level 2, and Level 3 Managers - into confidence quartiles. Panel A compares the average price benchmarks across repurchase quarters and non-repurchase quarters. Diff is the difference between the price benchmark in repurchase quarters and in non-repurchase quarters. Panel B tests whether the differences across each particular confidence quartile $(1,2,3)$ and the control quartile (0) within columns 4, 7, 10, 13, and 16 are statistically significant. The results in Panel B are t-statistics. All price variables are winsorized at the 1st and 99th percentiles. 
The results for Level 1, which contains the CEO, and Level 2, which contains the CFO, generally confirm the results in Table 3. For brevity, this paper focuses largely on the Low Price analysis (columns 11-13). Looking at Level 1 quartile 0 , the most moderately confident group, there is no statistically significant difference in pricing benchmarks across all measures. Within Level 1, the presence of a single overconfident insider is associated with a 0.06 higher log stock price in repurchase quarters relative to non-repurchase quarters. The difference is even greater when there are two or three overconfident insiders. The results for Level 2 and Level 3 further support the notion that overconfidence is associated with increased repurchase prices. For example, data for the most overconfident quartiles $(2 \& 3)$, suggest that overconfident companies repurchase in quarters where the low stock price is between approximately 11 and 17\% higher than non-repurchase quarters. This general trend is supported by the other price benchmarks. Once again, the statistics within Panel B confirm the hypothesis that the premiums paid significantly increase as companies become more saturated with overconfident insiders.

To further support the analyses, overconfidence's effect on repurchases is tested in a more formal regression setting. Table 5 examines repurchase efficiency in a panel regression setting that includes both firm-fixed effects and quarter-fixed effects. The dependent variable is either a $(\log )$ price benchmark or a valuation ratio and the independent variable is a repurchase quarter dummy variable equal to 1 if the firm repurchases at least $0.1 \%$ of its shares in that quarter (first column for each dependent variable), or at least $0.1 \%$ of its shares and the amount repurchased exceeds $\$ 10$ million (second column for each dependent variable), and 0 otherwise. Analysis of both samples suggests that as overconfidence increases, repurchasing efficiency decreases; however, the decrease is much more pronounced for larger repurchases and in this instance even moderately overconfident managers appear to poorly time their repurchases, although less so than overconfident managers.

Looking at the first row for the No Overconfident group, in which both the CEO and CFO are moderately confident, the regression coefficient suggests that repurchases made by moderately confident managers actually occur at prices that are lower than the average and maximum price benchmarks $(3.73 \%$ and $2.37 \%$ lower, respectively) and at prices that are not significantly different from the minimum price for non-repurchase quarters. Looking at overconfident managers suggests a different picture. Consider the Dual Overconfident group: here, the repurchase quarter dummy is positive and significant for all price benchmarks (once again, please consider the inherent noisiness of market-to-book ratios). Firms with an overconfident CEO and CFO seem to repurchase in months with significantly higher prices. In general, the findings point to the conclusion that moderately confident managers appear to do a relatively good job of timing their repurchases, while overconfident managers do not.

Following Bonaime et al. (2014), this paper only flags as repurchase quarters those with repurchases of at least $\$ 10$ million, essentially twice as large as the median repurchase. In these instances, overconfidence continues to be associated with increased repurchase premiums, but now moderately confident managers are also overpaying, albeit to a lesser extent, for their repurchased shares. In particular, for the average closing price benchmark, moderately confident repurchases are correlated with an approximate 5\% increase in the average closing stock price compared to 10 and $13 \%$ in the respective overconfidence groups. This linear trend is consistent across all price benchmarks and the $\mathrm{S} / \mathrm{P}$ valuation ratio. This is consistent with earlier findings by Bonaime et al. (2014) who suggest that smaller systematic repurchase strategies outperform the repurchase strategies currently used by many corporations. 


\section{TABLE 5 \\ REPURCHASE EFFICIENCY AND OVERCONFIDENCE-CEOS AND CFOs}

CEOS and CFOs

\begin{tabular}{|c|c|c|c|c|c|c|c|c|c|c|c|}
\hline \multirow[t]{3}{*}{ Confidence Group } & \multirow{2}{*}{$\begin{array}{l}\text { Dependent Variable } \\
\text { Repurchase }>0.1 \%\end{array}$} & \multicolumn{2}{|c|}{ Average Closing Price } & Minimum & \multicolumn{3}{|c|}{ Closing Price/aximium Closing Pric } & \multicolumn{2}{|c|}{$M / B_{t}$} & \multicolumn{2}{|c|}{$S / P_{t}$} \\
\hline & & $\begin{array}{c}-0.0373^{* *} \\
(-2.449)\end{array}$ & & $\begin{array}{l}-0.00713 \\
(-0.471)\end{array}$ & & $\begin{array}{l}-0.0237^{*} \\
(-1.662)\end{array}$ & & $\begin{array}{c}-0.215 * * * \\
(-3.295)\end{array}$ & & $\begin{array}{l}0.00919 \\
(1.067)\end{array}$ & \\
\hline & Repurchase $>0.1 \%$ & & $0.0489 * *$ & & $0.0741^{* * *}$ & & $0.0606 * * *$ & & -0.0383 & & -0.0132 \\
\hline \multirow[t]{9}{*}{ No Overconfident } & & & $(2.477)$ & & (3.719) & & $(3.210)$ & & $(-0.341)$ & & $(-1.176)$ \\
\hline & & $2.207^{* * *}$ & $2.169 * * *$ & $1.978^{* * *}$ & $1.960^{* * *}$ & $2.321^{* * *}$ & $2.291^{* * *}$ & $2.898^{* * *}$ & $2.727^{* * *}$ & $0.252^{*}$ & $0.261^{*}$ \\
\hline & & $(15.03)$ & $(14.90)$ & $(14.11)$ & $(13.79)$ & $(17.09)$ & $(16.66)$ & $(5.931)$ & $(5.679)$ & $(1.652)$ & $(1.730)$ \\
\hline & N & 15,022 & 15,022 & 15,022 & 15,022 & 15,022 & 15,022 & 14,953 & 14,953 & 14,942 & 14,942 \\
\hline & R-Squared & 0.699 & 0.699 & 0.722 & 0.722 & 0.699 & 0.699 & 0.460 & 0.459 & 0.769 & 0.769 \\
\hline & & 0.00718 & & $0.0353^{* * *}$ & & 0.0104 & & $-0.153^{* * *}$ & & -0.00339 & \\
\hline & Repurchase $>0.1 \%$ & $(0.582)$ & & $(2.876)$ & & $(0.887)$ & & $(-3.038)$ & & $(-0.504)$ & \\
\hline & & & $0.0986^{* * *}$ & & $0.129 * * *$ & & $0.0962^{* * *}$ & & 0.134 & & $-0.0297^{* * *}$ \\
\hline & $\begin{array}{l}\text { Repurchase >0.1\% } \\
\text { and } \$ 10 \text { Million }\end{array}$ & & $(6.143)$ & & (8.018) & & (6.321) & & $(1.637)$ & & $(-4.496)$ \\
\hline \multirow[t]{8}{*}{ Single Overconfident } & & $2.299 * * *$ & $2.299 * * *$ & $2.054^{* * *}$ & $2.064^{* * *}$ & $2.601^{* * *}$ & $2.602 * * *$ & $3.541 * * *$ & $3.480^{* * *}$ & $0.160^{* * *}$ & $0.160^{* * *}$ \\
\hline & & $(19.51)$ & $(20.34)$ & $(18.03)$ & $(19.25)$ & (23.38) & $(24.45)$ & $(7.696)$ & (7.722) & $(5.495)$ & $(5.581)$ \\
\hline & $\mathrm{N}$ & 24,417 & 24,417 & 24,417 & 24,417 & 24,417 & 24,417 & 24,370 & 24,370 & 24,348 & 24,348 \\
\hline & R-Squared & 0.674 & 0.676 & 0.692 & 0.694 & 0.673 & 0.675 & 0.548 & 0.548 & 0.757 & 0.757 \\
\hline & & $0.0361^{* *}$ & & $0.0626 * * *$ & & $0.0348^{* *}$ & & $-0.158^{* * *}$ & & -0.00367 & \\
\hline & Repurchase $>0.1 \%$ & $(2.383)$ & & $(4.109)$ & & $(2.422)$ & & $(-2.802)$ & & $(-0.509)$ & \\
\hline & & & $0.129 * * *$ & & $0.152^{* * *}$ & & $0.134^{* * *}$ & & 0.0465 & & $-0.0271^{* * *}$ \\
\hline & $\begin{array}{l}\text { Repurchase >0.1\% } \\
\text { and \$10 Million }\end{array}$ & & (5.989) & & $(6.824)$ & & $(6.665)$ & & $(0.467)$ & & $(-3.200)$ \\
\hline \multirow[t]{4}{*}{ Dual Overconfident } & & $3.234^{* * *}$ & $3.170^{* * *}$ & $3.115^{* * *}$ & $3.053^{* * *}$ & $3.540^{* * *}$ & $3.470^{* * *}$ & $5.446 * *$ & $5.297^{* *}$ & 0.155 & 0.172 \\
\hline & & $(17.02)$ & $(15.51)$ & $(14.61)$ & $(13.39)$ & $(14.75)$ & $(13.36)$ & $(2.501)$ & $(2.381)$ & $(1.376)$ & $(1.471)$ \\
\hline & $\mathrm{N}$ & 16,354 & 16,354 & 16,354 & 16,354 & 16,354 & 16,354 & 16,298 & 16,298 & 16,286 & 16,286 \\
\hline & R-Squared & 0.622 & 0.625 & 0.646 & 0.648 & 0.622 & 0.625 & 0.459 & 0.458 & 0.719 & 0.719 \\
\hline
\end{tabular}

Robust t-statistics in parentheses

${ }^{* * *} p<0.01,{ }^{* *} p<0.05,{ }^{*} p<0.1$

This table presents firm fixed effect regressions of split-adjusted stock price and valuation ratios on repurchase quarter dummies and quarterly time dummies separated across confidence quartiles and includes only CEOs and CFOs. No Overconfident consists of firms where both the CEO and CFO are moderately confident. Single Overconfident consists of firms where either the CEO or the CFO is overconfident. Dual Overconfident consists of firms where both the CEO and CFO are overconfident. The repurchase dummy is 1 if total stock repurchases made within the quarter are at least 0.1 percent of market capitalization or 0.1 percent of market capitalization and $\$ 10$ million, as noted. Average closing price is the natural log of mean daily closing price. Minimum closing price is the natural $\log$ of the minimum daily closing price. Maximum closing price is the natural $\log$ of the maximum daily closing price. $M / B$ is the market capitalization divided by the value of common equity. $S / P$ is the total quarterly sales divided by quarterly market capitalization. The value of each variable is also measured at the end of the current quarter (marked with subscript $t$ ). All standard errors are clustered by firm. 
Table 6 extends Table 5 to include all insiders; the results echo those provided in Table 5. Looking at the price benchmarks (columns 1,3, and 5), the results offer more evidence that overconfidence is associated with increased repurchase prices. Column 1 regresses quarterly average (logged) daily closing prices on the repurchase dummy, firm fixed-effects, and quarterly fixed-effects. The negative coefficient in Confidence Group 0 suggests that firms with no overconfident insiders repurchased during quarters in which the average daily closing price was approximately $4 \%$ lower than non-repurchase quarters. As overconfidence levels within the companies increase, in Confidence Groups 1, 2, and 3 this coefficient increases to the point where the most overconfident repurchases are made during quarters with average daily closing prices that are almost $6 \%$ higher. Looking at columns 3 and 5, the results suggest a similar pattern. Repurchases made by Confidence Group 0 are not correlated with any statistically significant increases in either the quarterly minimum closing price or the maximum closing price. As overconfidence increases there is a steady decrease in repurchase efficiency: for Confidence Group 3, repurchases are made in quarters with prices $17-20 \%$ higher than non-repurchase quarters.

Columns 2, 4, 6, 8, and 10 perform similar regressions as above, but with a repurchase dummy threshold of $\$ 10$ million. Similar to Table 5, all confidence groups now appear to repurchase at prices that are too high. To put this in perspective, using the minimum closing price (Column 4) as a best-case scenario, a moderately confident company repurchasing \$10 million at the quarter's minimum share price could have saved approximately $\$ 1.2$ million by purchasing the shares during an average non-repurchase quarter. This increases to $\$ 2.05$ million in the most overconfident firms.

TABLE 6

REPURCHASE EFFICIENCY AND OVERCONFIDENCE - ALL INSIDERS

\begin{tabular}{|c|c|c|c|c|c|c|c|c|c|c|c|}
\hline \multirow[t]{2}{*}{ Confidence Group } & \multirow[t]{2}{*}{ Dependent Variable } & \multicolumn{2}{|c|}{$\begin{array}{l}\text { Average Closing } \\
\text { Price }\end{array}$} & \multicolumn{2}{|c|}{$\begin{array}{c}\text { Minimum Closing } \\
\text { Price }\end{array}$} & \multicolumn{2}{|c|}{$\begin{array}{c}\text { Maximium Closing } \\
\text { Price }\end{array}$} & \multicolumn{2}{|c|}{$\mathbf{M} / \mathbf{B}_{\mathbf{t}}$} & \multicolumn{2}{|c|}{$\mathbf{S} / \mathbf{P}_{\mathbf{t}}$} \\
\hline & & (1) & (2) & (3) & (4) & (5) & (6) & (7) & (8) & (9) & (10) \\
\hline \multirow{5}{*}{0} & Repurchase $>0.1 \%$ & $\begin{array}{c}-0.0412 * * * \\
(-2.692)\end{array}$ & & $\begin{array}{l}-0.0123 \\
(-0.773)\end{array}$ & & $\begin{array}{l}-0.0188 \\
(-1.343)\end{array}$ & & $\begin{array}{l}-0.152 * * \\
(-2.359)\end{array}$ & & $\begin{array}{c}0.00448 \\
(0.536)\end{array}$ & \\
\hline & $\begin{array}{l}\text { Repurchase }>0.1 \% \\
\text { and } \$ 10 \text { Million }\end{array}$ & & $\begin{array}{l}0.0849 * * * \\
(4.399)\end{array}$ & & $\begin{array}{c}0.121 * * * \\
(6.054)\end{array}$ & & $\begin{array}{l}0.103 * * * \\
(5.737)\end{array}$ & & $\begin{array}{l}0.0291 \\
(0.269)\end{array}$ & & $\begin{array}{l}-0.0178 \\
(-1.578)\end{array}$ \\
\hline & Constant & $\begin{array}{l}2.578^{* * * *} \\
(795.1)\end{array}$ & $\begin{array}{l}2.570^{* * * *} \\
(855.4)\end{array}$ & $\begin{array}{c}2.277 * * * \\
(690.3)\end{array}$ & $\begin{array}{l}2.270 * * * \\
(756.4)\end{array}$ & $\begin{array}{l}2.830^{* * * *} \\
(945.4)\end{array}$ & $\begin{array}{c}2.823 * * * \\
(1,042)\end{array}$ & $\begin{array}{c}2.599 * * * \\
(132.4)\end{array}$ & $\begin{array}{l}2.582 * * * \\
(135.8)\end{array}$ & $\begin{array}{l}0.121^{* * *} \\
(43.11)\end{array}$ & $\begin{array}{l}0.122 * * * \\
(45.09)\end{array}$ \\
\hline & $\mathrm{N}$ & 14,584 & 14,584 & 14,584 & 14,584 & 14,584 & 14,584 & 14,530 & 14,530 & 14,519 & 14,519 \\
\hline & R-Squared & 0.688 & 0.688 & 0.692 & 0.694 & 0.695 & 0.697 & 0.497 & 0.496 & 0.765 & 0.765 \\
\hline \multirow{5}{*}{-} & Repurchase $>0.1 \%$ & $\begin{array}{c}-0.00697 \\
(-0.473)\end{array}$ & & $\begin{array}{r}0.0236 \\
(1.531)\end{array}$ & & $\begin{array}{c}0.00676 \\
(0.487)\end{array}$ & & $\begin{array}{l}-0.0784 \\
(-1.072)\end{array}$ & & $\begin{array}{l}-0.00815 \\
(-1.364)\end{array}$ & \\
\hline & $\begin{array}{l}\text { Repurchase }>0.1 \% \\
\text { and } \$ 10 \text { Million }\end{array}$ & & $\begin{array}{l}0.109 * * * \\
(5.696)\end{array}$ & & $\begin{array}{l}0.154 * * * \\
(7.972)\end{array}$ & & $\begin{array}{l}0.109^{* * *} \\
(5.867)\end{array}$ & & $\begin{array}{c}0.170 \\
(1.391)\end{array}$ & & $\begin{array}{c}-0.0333 * * * \\
(-4.952)\end{array}$ \\
\hline & Constant & $\begin{array}{l}2.839 * * * \\
(904.4)\end{array}$ & $\begin{array}{c}2.827 * * * \\
(818.9)\end{array}$ & $\begin{array}{c}2.611 * * * \\
(812.4)\end{array}$ & $\begin{array}{c}2.598 * * * \\
(751.1)\end{array}$ & $\begin{array}{c}3.073 * * * \\
(1,076)\end{array}$ & $\begin{array}{c}3.063 * * * \\
(960.9)\end{array}$ & $\begin{array}{c}1.063 * * * \\
(55.97)\end{array}$ & $\begin{array}{c}1.039 * * * \\
(47.98)\end{array}$ & $\begin{array}{c}1.056^{* * * *} \\
(444.2)\end{array}$ & $\begin{array}{c}1.058^{* * * *} \\
(452.2)\end{array}$ \\
\hline & $\mathrm{N}$ & 16,918 & 16,918 & 16,918 & 16,918 & 16,918 & 16,918 & 16,844 & 16,844 & 16,817 & 16,817 \\
\hline & R-Squared & 0.661 & 0.664 & 0.663 & 0.667 & 0.672 & 0.675 & 0.544 & 0.544 & 0.782 & 0.782 \\
\hline \multirow{5}{*}{$\sim$} & Repurchase $>0.1 \%$ & $\begin{array}{l}0.0178 \\
(1.053)\end{array}$ & & $\begin{array}{l}0.0535^{* * *} \\
(3.079)\end{array}$ & & $\begin{array}{l}0.0278^{*} \\
(1.821)\end{array}$ & & $\begin{array}{l}0.00860 \\
(0.145)\end{array}$ & & $\begin{array}{l}-0.0114 \\
(-1.469)\end{array}$ & \\
\hline & $\begin{array}{l}\text { Repurchase }>0.1 \% \\
\text { and } \$ 10 \text { Million }\end{array}$ & & $\begin{array}{c}0.138 * * * \\
(6.172)\end{array}$ & & $\begin{array}{l}0.187 * * * \\
(8.161)\end{array}$ & & $\begin{array}{l}0.132 * * * \\
(6.253)\end{array}$ & & $\begin{array}{c}0.147 \\
(1.379)\end{array}$ & & $\begin{array}{c}-0.0364 * * * \\
(-3.929)\end{array}$ \\
\hline & Constant & $\begin{array}{l}2.490 * * * \\
(788.1)\end{array}$ & $\begin{array}{c}2.488^{* * * *} \\
(766.2)\end{array}$ & $\begin{array}{l}2.269^{* * * *} \\
(699.0)\end{array}$ & $\begin{array}{c}2.267 * * * \\
(696.0)\end{array}$ & $\begin{array}{c}2.753 * * * \\
(1,010)\end{array}$ & $\begin{array}{l}2.751 * * * \\
(991.8)\end{array}$ & $\begin{array}{c}2.810^{* * *} \\
(188.5)\end{array}$ & $\begin{array}{l}2.807 * * * \\
(183.1)\end{array}$ & $\begin{array}{l}0.234 * * * \\
(71.40)\end{array}$ & $\begin{array}{l}0.235^{* * *} \\
(72.45)\end{array}$ \\
\hline & $\mathrm{N}$ & 16,784 & 16,784 & 16,784 & 16,784 & 16,784 & 16,784 & 16,737 & 16,737 & 16,725 & 16,725 \\
\hline & R-Squared & 0.655 & 0.658 & 0.651 & 0.655 & 0.673 & 0.676 & 0.467 & 0.468 & 0.679 & 0.679 \\
\hline \multirow{5}{*}{$m$} & Repurchase $>0.1 \%$ & $\begin{array}{l}0.0573^{* * * *} \\
(3.832)\end{array}$ & & $\begin{array}{l}0.0891 * * * \\
(5.758)\end{array}$ & & $\begin{array}{l}0.0551^{* * *} \\
(3.999)\end{array}$ & & $\begin{array}{l}-0.0584 \\
(-1.327)\end{array}$ & & $\begin{array}{l}-0.0173^{* *} \\
(-2.169)\end{array}$ & \\
\hline & $\begin{array}{l}\text { Repurchase }>0.1 \% \\
\text { and } \$ 10 \text { Million }\end{array}$ & & $\begin{array}{l}0.170^{* * *} \\
(8.833)\end{array}$ & & $\begin{array}{c}0.205^{* * *} \\
(10.11)\end{array}$ & & $\begin{array}{c}0.171 * * * \\
(9.656)\end{array}$ & & $\begin{array}{c}0.115 \\
(1.615)\end{array}$ & & $\begin{array}{c}-0.0414 * * * \\
(-5.445)\end{array}$ \\
\hline & Constant & $\begin{array}{c}2.897 * * * \\
(360.1)\end{array}$ & $\begin{array}{c}2.928 * * * \\
(1,067)\end{array}$ & $\begin{array}{c}2.649^{* * * *} \\
(315.4)\end{array}$ & $\begin{array}{c}2.698 * * * \\
(988.4)\end{array}$ & $\begin{array}{c}3.099 * * * \\
(419.1)\end{array}$ & $\begin{array}{c}3.129 * * * \\
(1,322)\end{array}$ & $\begin{array}{c}4.012 * * * \\
(141.1)\end{array}$ & $\begin{array}{c}3.981 * * * \\
(277.0)\end{array}$ & $\begin{array}{c}0.0805^{* * *} \\
(15.54)\end{array}$ & $\begin{array}{c}0.0711^{* * *} \\
(25.24)\end{array}$ \\
\hline & $\mathrm{N}$ & 22,135 & 22,135 & 22,135 & 22,135 & 22,135 & 22,135 & 22,085 & 22,085 & 22,073 & 22,073 \\
\hline & R-Squared & 0.574 & 0.577 & 0.581 & 0.585 & 0.585 & 0.589 & 0.447 & 0.447 & 0.730 & 0.730 \\
\hline
\end{tabular}

142 Journal of Accounting and Finance Vol. 19(4) 2019 
This table presents firm-fixed effect regressions of split-adjusted stock price and valuation ratios on repurchase quarter dummies and quarterly time dummies separated across confidence quartiles and includes all corporate insiders. Confidence group 0 consists of firms where all corporate insiders are moderately confident. The number of overconfident insiders increases as the confidence group number increases. Confidence group 3 consists of firms with the largest number of overconfident insiders. The repurchase dummy is 1 if total stock repurchases made within the quarter are at least 0.1 percent of market capitalization or 0.1 percent of market capitalization and $\$ 10$ million, as noted. Average closing price is the natural log of mean daily closing price. Minimum closing price is the natural $\log$ of the minimum daily closing price. Maximum closing price is the natural $\log$ of the maximum daily closing price. $M / B$ is the market capitalization divided by the value of common equity. $S / P$ is the total quarterly sales divided by quarterly market capitalization. The value of each variable is also measured at the end of the current quarter (marked with subscript $t$ ). All standard errors are clustered by firm.

\section{Overconfidence, Repurchasing, and Share Liquidity}

Lastly, this paper addresses the question: how do repurchases affect a company's liquidity? There are two popular opposing hypotheses, both suggested by Barclay and Smith (1988). On one hand, it is suggested that regular repurchases may decrease the bid-ask spread. As managers submit limit orders to buy stock, they establish a lower bound for a stock and narrow the bid-ask spread. On the other hand, an asymmetric information problem may exist that widens spreads. When market makers recognize the presence of an informed trader (the repurchasing company), they may react by widening their spread to compensate for their losses.

This paper conjectures that firms led by overconfident managers are more likely to be perceived as uninformed traders, while firms led by moderately confident managers are more likely to be perceived as informed traders who are attempting to time the market. Thus, holding all else equal, spreads are expected to be relatively lower when firms with overconfident executives are repurchasing shares, and relatively higher when firms with moderately confident executives are repurchasing. Table 7 provides results consistent with this conjecture. This paper regresses average quarterly bid-ask spreads on a number of control variables, as well as indicators related to repurchase quarters and the level of managerial overconfidence. As shown in column 1, repurchases in general are correlated with a $20 \%$ increase in the average bid-ask spread. Because the included categorical variables use moderately confident nonrepurchase quarters as the control group, it is concluded that moderately confident repurchases are related to lower liquidity. The presence of a single overconfident CFO or CEO does not appear to generally affect firm liquidity; however, having both an overconfident CEO and an overconfident CFO is related to higher bid-ask spreads.

The main variables of interest are the interaction terms because they shine light on how managerial overconfidence and repurchases collectively affect liquidity. The interaction between the Repi variable, defined as 1 if repurchases made during the quarter are at least 0.1 percent of market capitalization and 0 otherwise, and overconfidence suggests that repurchases actually decrease bid-ask spreads by $18 \%$ for both Single Overconfident firms and Dual Overconfident firms. Column 2 considers all insiders, but rather than splitting confidence groups into quartiles, it uses an Overconfident dummy that is 1 if at least one manager is overconfident and 0 otherwise. The results suggest that moderately confident repurchases are related to higher spreads, while overconfident repurchases are correlated with a $9 \%$ spread decrease. Such results intuitively support the idea that moderately confident firms repurchase based on private information in an attempt to repurchase at abnormally low prices. ${ }^{1}$ In contrast, overconfident managers either poorly time the market or repurchase for other reasons, and thereby increase liquidity. 


\section{TABLE 7 \\ SHARE LIQUIDITY AND OVERCONFIDENCE}

\begin{tabular}{|c|c|c|}
\hline VARIABLES & $\begin{array}{c}\text { CEO and CFO } \\
\text { (1) }\end{array}$ & $\begin{array}{c}\text { All Insiders } \\
(2)\end{array}$ \\
\hline Repi & $\begin{array}{l}0.20^{* * *} \\
(0.052)\end{array}$ & $\begin{array}{l}0.12^{* * *} \\
(0.035)\end{array}$ \\
\hline Single Overconfident & $\begin{array}{c}0.03 \\
(0.055)\end{array}$ & \\
\hline Dual Overconfident & $\begin{array}{l}0.13^{* *} \\
(0.054)\end{array}$ & \\
\hline Single*Repi & $\begin{array}{c}-0.18^{* * *} \\
(0.064)\end{array}$ & \\
\hline Dual*Repi & $\begin{array}{c}-0.18^{* * *} \\
(0.060)\end{array}$ & \\
\hline Overconfident & & $\begin{array}{l}0.09 * * * \\
(0.031)\end{array}$ \\
\hline Overconfident*Repi & & $\begin{array}{l}-0.09 * * \\
(0.039)\end{array}$ \\
\hline Fsize & $\begin{array}{l}0.17^{* * *} \\
(0.022)\end{array}$ & $\begin{array}{l}0.15^{* * *} \\
(0.015)\end{array}$ \\
\hline Close & $\begin{array}{c}-0.15^{* * *} \\
(0.027)\end{array}$ & $\begin{array}{c}-0.13^{* * *} \\
(0.018)\end{array}$ \\
\hline Volume & $\begin{array}{c}-0.45^{* * *} \\
(0.013)\end{array}$ & $\begin{array}{c}-0.44^{* * *} \\
(0.009)\end{array}$ \\
\hline Volatility & $\begin{array}{l}7.99 * * * \\
(0.824)\end{array}$ & $\begin{array}{l}9.48^{* * *} \\
(0.586)\end{array}$ \\
\hline Constant & $\begin{array}{l}4.59 * * * \\
(0.228)\end{array}$ & $\begin{array}{l}4.33^{* * *} \\
(0.145)\end{array}$ \\
\hline Observations & 25,196 & 51,876 \\
\hline R-squared & 0.50 & 0.50 \\
\hline
\end{tabular}

Robust standard errors in parentheses $* * * p<0.01, * * p<0.05, * p<0.1$

This table presents regressions of average quarterly bid-ask spreads on a stock repurchase dummy and various overconfidence measures. Repi is a quarterly repurchase dummy: 1 if repurchases made during the quarter are at least 0.1 percent of market capitalization. Single Overconfident is a dummy variable equal to 1 if only the CEO or CFO is overconfident. Dual Overconfident is a dummy variable equal to 1 if both the CEO and CFO are overconfident. Overconfident is a dummy variable equal to one if at least one insider is deemed overconfident by the confidence scale of Kolasinski and $\mathrm{Li}$ (2013). Fsize is the natural log of firm total assets. Close is the natural log of the average daily closing stock price. Volume is the natural log of total shares traded during the quarter. Volatility is the natural $\log$ of the standard deviation of quarterly stock returns. All standard errors are clustered by firm. 


\section{CONCLUSION}

This study is motivated by the observation that behavioral biases like managerial overconfidence can have a great impact on many corporate decisions. The interaction between overconfidence and the way that firms carry out their open market repurchase programs is the main focus. This paper finds that overconfident managers are more likely to repurchase at higher prices, while moderately confident managers seem to repurchase at lower prices and during periods of relative undervaluation. In general, this paper finds that overconfidence can help to explain previous findings that managers are poor at timing repurchases. Overconfident managers repurchase much less efficiently than their more moderately confident peers. The results suggest that the presence of an overconfident CEO or CFO can increase the repurchase price premium by $3.5 \%$ and over $6 \%$ if both the $\mathrm{CEO}$ and $\mathrm{CFO}$ are overconfident. In contrast, no statistically significant price premium paid by moderately confident CEOs is found if using the minimum price benchmark. In fact, using the average closing price benchmark, moderately confident managers could potentially be repurchasing at over a $3 \%$ discount. If the overconfidence classification system is extended to include more corporate insiders within the sample, the same general pattern is observed - as insider overconfidence increases, firms repurchase less efficiently. This paper also provides important new evidence on the relationship between share repurchases and stock market liquidity. Repurchases by firms with overconfident managers seem to be related to periods of lower bid-ask spreads. This result may provide an important perspective on the conflicting findings of Cook, Krigman, and Leach (2004) and Brockman and Chung (2001), in that repurchases may have different effects on liquidity depending on the confidence levels of the firm's leaders.

Ultimately, this paper concludes that overconfident managers repurchase in a very different fashion than their more moderately confident peers. Moderately confident managers seem to time their repurchases well, and this is recognized by market participants. Overconfident managers, on the other hand, are much less efficient in their repurchasing behavior. Consistent with Warren Buffett's conjecture in the opening quote, the results suggest that the optimal payout policy of a particular firm may be dependent on the behavioral characteristics of its managers.

\section{ACKNOWLEDGEMENT}

I am grateful to Shane Underwood, Douglas Cook, Shawn Mobbs, Marcus Perry, Brad Daughdrill, and seminar participants at the University of Alabama for helpful comments and suggestions. I am also grateful to reviewing seminar participants at the 2015 FMA Annual Meeting and to Virginia Gerde and Thomas Smythe at Furman University. All errors are my own.

\section{ENDNOTES}

1. Splitting the Overconfident dummy into 4 quartiles, as done in earlier tables, yields similar results.

2. For a detailed description of the Longholder and other methods, see Malmendier and Tate (2011). 


\section{REFERENCES}

Alicke, M. D. (1985). Global self-evaluation as determined by the desirability and controllability of trait adjectives. Journal of Personality and Social Psychology, 49(6), 1621.

Alicke, M. D., Klotz, M. L., Breitenbecher, D. L., Yurak, T. J., \& Vredenburg, D. S. (1995). Personal contact, individuation, and the better-than-average effect. Journal of Personality and Social Psychology, 68(5), 804.

Allen, F., \& Michaely, R. (2003). Payout policy. Handbook of the Economics of Finance, 1, 337-429.

Andriosopoulos, D., Andriosopoulos, K., \& Hoque, H. (2013). Information disclosure, CEO overconfidence, and share buyback completion rates. Journal of Banking and Finance, 37(12), 5486-5499.

Bagwell, L. S., \& Shoven, J. B. (1988). Share repurchases and acquisitions: An analysis of which firms participate. University of Chicago Press.

Baker, M., \& Wurgler, J. (2002). Market timing and capital structure. The Journal of Finance, 57(1), 132.

Bajaj, M., \& Vijh, A. M. (1990). Dividend clienteles and the information content of dividend changes. Journal of Financial Economics, 26(2), 193-219.

Banerjee, S., Humphery-Jenner, M., \& Nanda, V. (2015). Does CEO Bias Escalate Repurchase Activity? Working paper, University of Wyoming.

Banyi, M. L., Dyl, E. A., \& Kahle, K. M. (2008). Errors in estimating share repurchases. Journal of Corporate Finance, 14(4), 460-474.

Barclay, M. J., \& Smith, C. W. (1988). Corporate payout policy: Cash dividends versus open-market repurchases. Journal of Financial Economics, 22(1), 61-82.

Bargeron, L., Kulchania, M., \& Thomas, S. (2011). Accelerated share repurchases. Journal of Financial Economics, 101(1), 69-89.

Bartov, E., \& Mohanram, P. (2004). Private information, earnings manipulations, and executive stockoption exercises. Accounting Review, 889-920.

Ben-Rephael, A., Oded, J., \& Wohl, A. (2013). Do Firms Buy Their Stock at Bargain Prices? Evidence from Actual Stock Repurchase Disclosures. Review of Finance, $\mathrm{rft} 028$.

Bhattacharya, U., \& Dittmar, A. (2003). Costless versus costly signalling: Theory and evidence from share repurchasing. Kelley School of Business Working Paper

Bonaimé, A. A. (2012). Repurchases, reputation, and returns. Journal of Financial and Quantitative Analysis, 47(02), 469-491.

Bonaimé, A. A., \& Ryngaert, M. D. (2013). Insider trading and share repurchases: Do insiders and firms trade in the same direction? Journal of Corporate Finance, 22, 35-53.

Bonaimé, A. A., Hankins, K. W., \& Jordan, B. D. (2014). Wiser to wait: Do firms optimally execute share repurchases? Available at SSRN 1977654.

Bonaimé, A. A., Hankins, K. W., \& Jordan, B. D. (2016). The cost of financial flexibility: Evidence from share repurchases. Journal of Corporate Finance, 38, 345-362.

Brav, A., Graham, J., Harvey, C., \& Michaely, R. (2005). Payout policy in the 21 st century. Journal of Financial Economics, 77(3), 483-527.

Brockman, P., \& Chung, D. Y. (2001). Managerial timing and corporate liquidity:: evidence from actual share repurchases. Journal of Financial Economics, 61(3), 417-448.

Brockman, P., Khurana, I. K., \& Martin, X. (2008). Voluntary disclosures around share repurchases. Journal of Financial Economics, 89(1), 175-191.

Camerer, C., \& Lovallo, D. (1999). Overconfidence and excess entry: An experimental approach. The American Economic Review, 89(1), 306-318.

Campbell, C., Johnson, S., Rutherford, J., \& Stanley, B. (2009). CEO confidence and forced turnover. Working paper, Texas A\&M University.

Chan, K., Ikenberry, D. L., Lee, I., \& Wang, Y. (2010). Share repurchases as a potential tool to mislead investors. Journal of Corporate Finance, 16(2), 137-158.

146 Journal of Accounting and Finance Vol. 19(4) 2019 
Chan, K., Ikenberry, D. L., Lee, I., \& Wang, Y. (2012). Informed Traders: Linking legal insider trading and share repurchases. Financial Analysts Journal, 68(1), 60-73.

Chen, S.-S., \& Wang, Y. (2012). Financial constraints and share repurchases. Journal of Financial Economics, 105(2), 311-331.

Cook, D. O., Krigman, L., \& Leach, J. C. (2003). An Analysis of SEC Guidelines for Executing Open Market Repurchases*. The Journal of Business, 76(2), 289-315.

Cook, D. O., Krigman, L., \& Leach, J. C. (2004). On the timing and execution of open market repurchases. Review of financial studies, 17(2), 463-498.

De Cesari, A., Espenlaub, S., \& Khurshed, A. (2011). Stock repurchases and treasury share sales: Do they stabilize price and enhance liquidity? Journal of Corporate Finance, 17(5), 1558-1579.

De Cesari, A., Espenlaub, S., Khurshed, A., \& Simkovic, M. (2012). The effects of ownership and stock liquidity on the timing of repurchase transactions. Journal of Corporate Finance, 18(5), 1023 1050.

Denis, D. J., Denis, D. K., \& Sarin, A. (1994). The information content of dividend changes: Cash flow signaling, overinvestment, and dividend clienteles. Journal of Financial and Quantitative Analysis, 29(04), 567-587.

Dittmar, A. K., \& Dittmar, R. F. (2008). The timing of financing decisions: An examination of the correlation in financing waves. Journal of Financial Economics, 90(1), 59-83.

Dittmar, A. K. (2000). Why Do Firms Repurchase Stock*. The Journal of Business, 73(3), 331-355.

Dittmar, A., \& Field, L. C. (2015). Can managers time the market? Evidence using repurchase price data. Journal of Financial Economics, 115(2), 261-282.

Feng, L., Pukthuanthong, K., Thiengtham, D., Turtle, H., \& Walker, T. J. (2013). The Effects of Cash, Debt, and Insiders on Open Market Share Repurchases. Journal of Applied Corporate Finance, 25(1), 55-63.

Finnerty, J. F. (1974). Special information and insider trading. Journal of finance, 31, 1141-1148.

Goel, A. M., \& Thakor, A. V. (2008). Overconfidence, CEO selection, and corporate governance. The Journal of Finance, 63(6), 2737-2784.

Gong, G., Louis, H., \& Sun, A. X. (2008). Earnings Management and Firm Performance Following OpenMarket Repurchases. The Journal of Finance, 63(2), 947-986.

Grullon, G., \& Michaely, R. (2002). Dividends, share repurchases, and the substitution hypothesis. The Journal of Finance, 57(4), 1649-1684.

Grullon, G., \& Michaely, R. (2004). The information content of share repurchase programs. The Journal of Finance, 59(2), 651-680.

Guay, W., \& Harford, J. (2000). The cash-flow permanence and information content of dividend increases versus repurchases. Journal of Financial Economics, 57(3), 385-415.

Ikenberry, D., Lakonishok, J., \& Vermaelen, T. (1995). Market underreaction to open market share repurchases. Journal of Financial Economics, 39(2-3), 181-208.

Ikenberry, D., Lakonishok, J., \& Vermaelen, T. (2000). Stock repurchases in Canada: Performance and strategic trading. The Journal of Finance, 55(5), 2373-2397.

Jensen, M. C. (1986). Agency costs of free cash flow, corporate finance, and takeovers. The American Economic Review, 76(2), 323-329.

Jiang, Z., Kim, K. A., Lie, E., \& Yang, S. (2013). Share repurchases, catering, and dividend substitution. Journal of Corporate Finance, 21, 36-50.

Kahel, M. (2002). When a Buyback Isn’t A Buyback: Open Market Repurchases and Employee Option. Journal of finance, 63, 235-261.

Kaplan, S. N., \& Reishus, D. (1990). Outside directorships and corporate performance. Journal of Financial Economics, 27(2), 389-410.

Kolasinski, A. C., \& Li, X. (2013). Can strong boards and trading their own firm's stock help CEOs make better decisions? Evidence from acquisitions by overconfident CEOs. Journal of Financial and Quantitative Analysis, 48(04), 1173-1206. 
Lakonishok, J., Shleifer, A., \& Vishny, R. W. (1994). Contrarian investment, extrapolation, and risk. The journal of finance, 49(5), 1541-1578.

Lakonishok, J., \& Lee, I. (2001). Are insider trades informative? Review of financial studies, 14(1), 7911.

Larwood, L., \& Whittaker, W. (1977). Managerial myopia: Self-serving biases in organizational planning. Journal of applied psychology, 62(2), 194.

Louis, H., Sun, A. X., \& White, H. (2010). Insider trading after repurchase tender offer announcements: Timing versus informed trading. Financial management, 39(1), 301-322.

Malmendier, U., \& Tate, G. (2005). CEO overconfidence and corporate investment. The Journal of Finance, 60(6), 2661-2700.

Malmendier, U., \& Tate, G. (2008). Who makes acquisitions? CEO overconfidence and the market's reaction. Journal of Financial Economics, 89(1), 20-43.

Malmendier, U., Tate, G., \& Yan, J. (2011). Overconfidence and Early-Life Experiences: The Effect of Managerial Traits on Corporate Financial Policies. The Journal of Finance, 66(5), 1687-1733.

McNally, W. J., Smith, B. F., \& Barnes, T. (2006). The price impacts of open market repurchase trades. Journal of Business Finance \& Accounting, 33(5-6), 735-752.

Michel, A., Oded, J., \& Shaked, I. (2010). Not all buybacks are created equal: The case of accelerated stock repurchases. Financial Analysts Journal, 66(6), 55.

Miller, D. T., \& Ross, M. (1975). Self-serving biases in the attribution of causality: Fact or fiction? Psychological bulletin, 82(2), 213.

Peyer, U., \& Vermaelen, T. (2009). The nature and persistence of buyback anomalies. Review of financial studies, 22(4), 1693-1745.

Stephens, C. P., \& Weisbach, M. S. (1998). Actual share reacquisitions in open-market repurchase programs. The Journal of Finance, 53(1), 313-333.

Svenson, O. (1981). Are we all less risky and more skillful than our fellow drivers? Acta Psychologica, 47(2), 143-148.

Weinstein, N. D. (1982). Unrealistic optimism about susceptibility to health problems. Journal of Behavioral Medicine, 5(4), 441-460.

Weston, J. (2000). Competition on the Nasdaq and the impact of recent market reforms. Journal of Finance, 55(6), 2565-2598. 


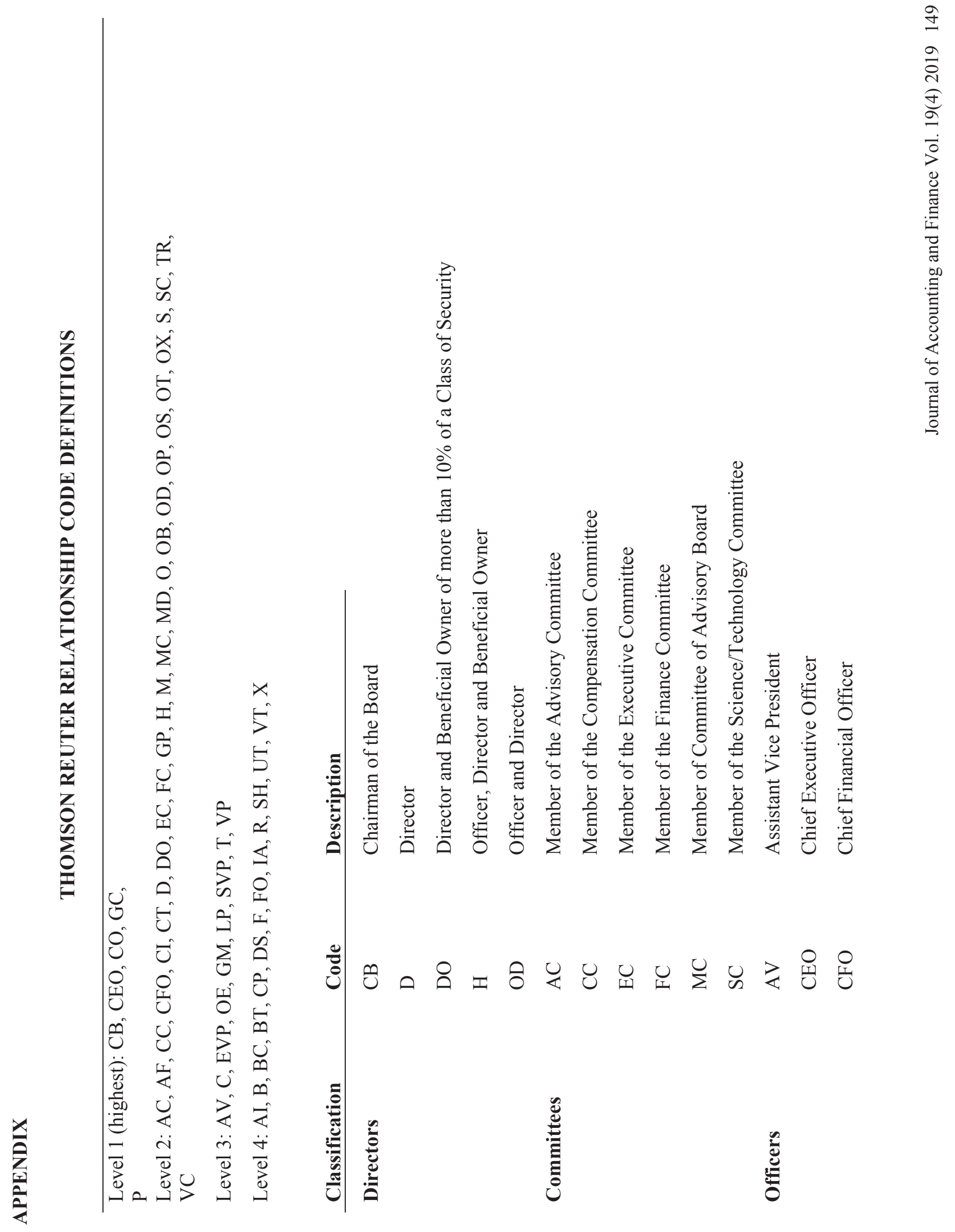




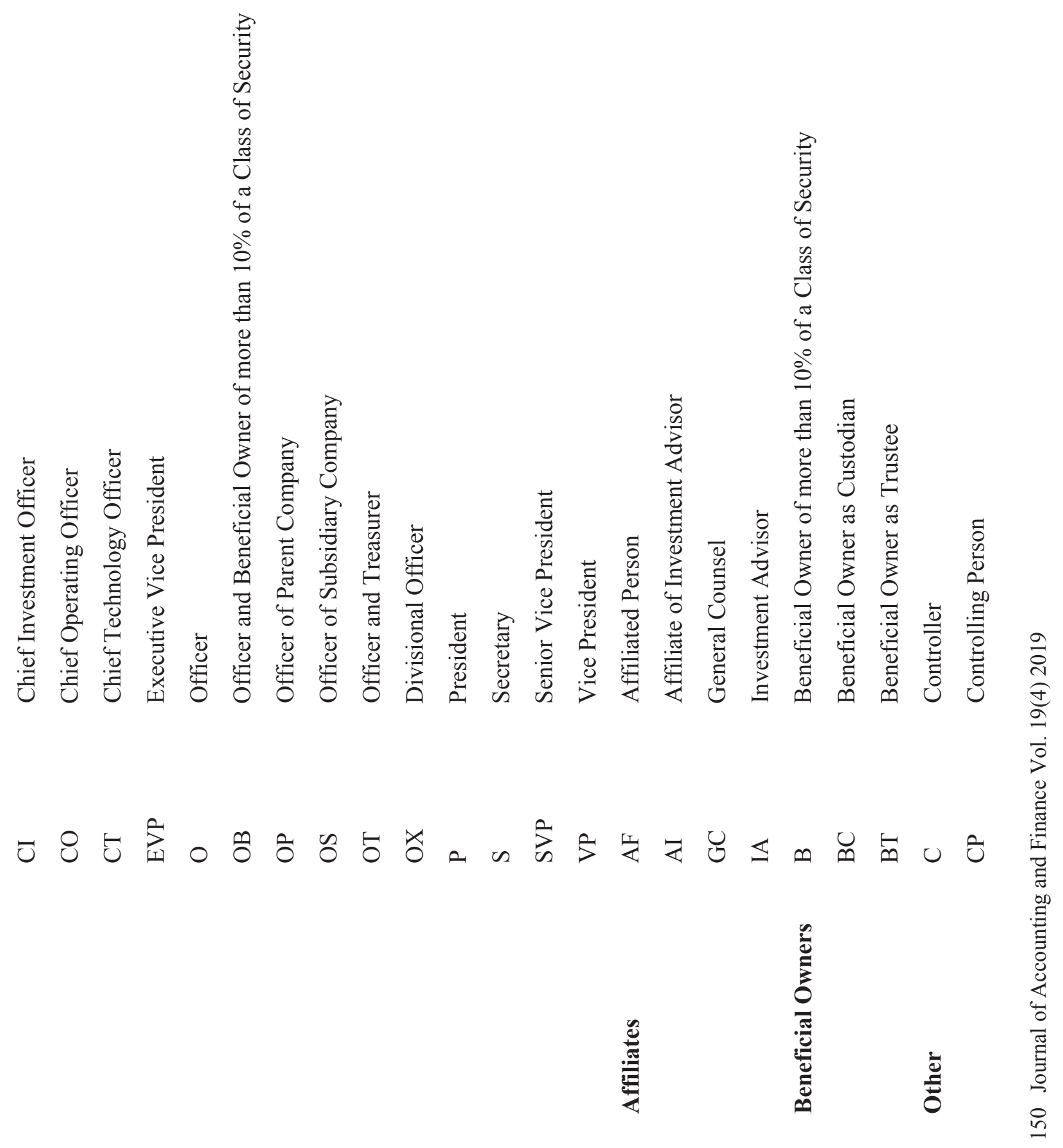




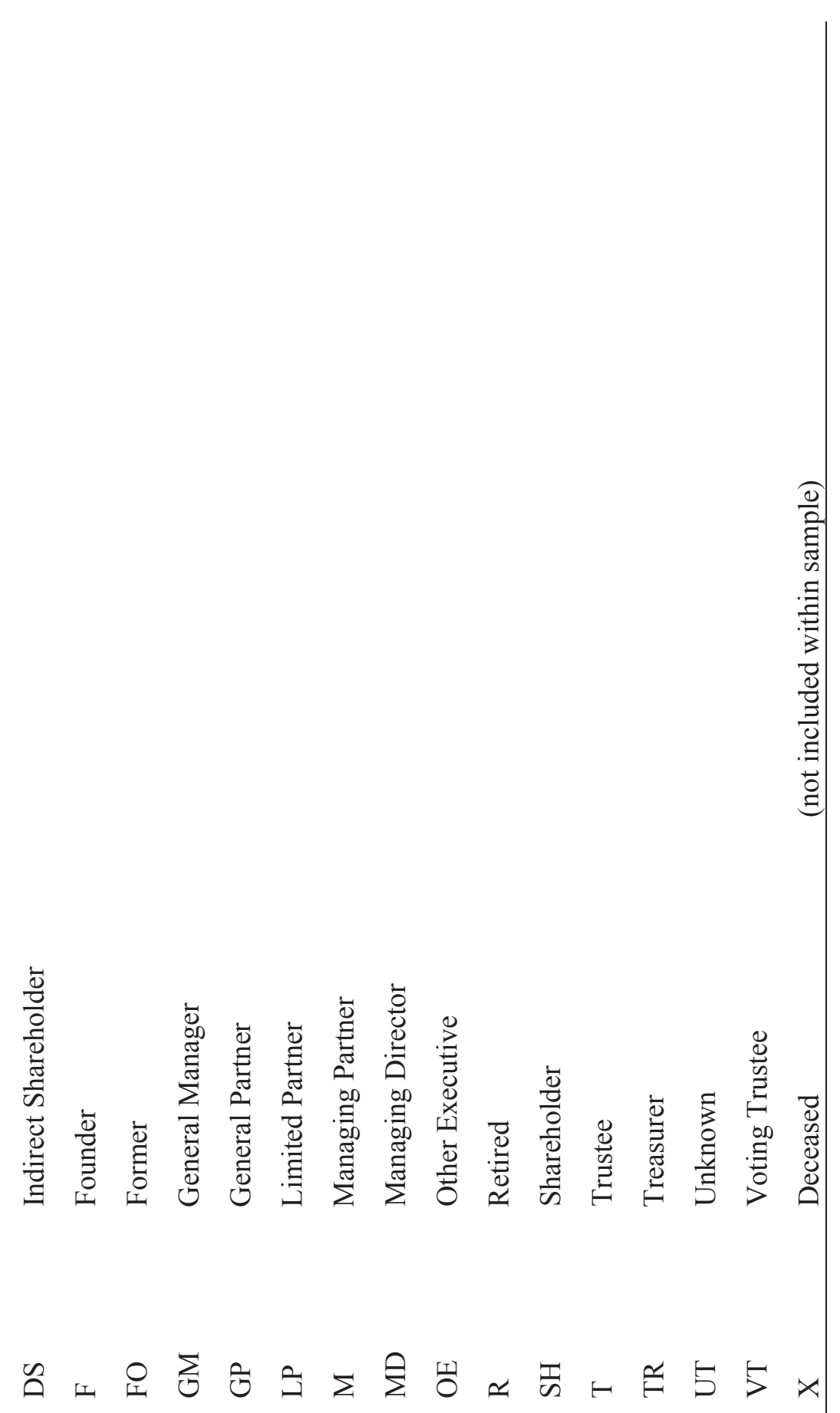

